\title{
The fishes of the Bolaman Stream, Northern Turkey
}

\section{Serkan SAYGUN}

Cite this article as:

Saygun, S. (2021). The fishes of the Bolaman Stream, Northern Turkey. Aquatic Research, 4(1), 38-54. https://doi.org/10.3153/AR21004

Ordu University, Fatsa Faculty of Marine Sciences, Department of Fisheries

Technology Engineering, 52400

Fatsa- Ordu/Turkey

ORCID IDs of the author(s):

S.S. 0000-0002-9789-3284

Submitted: 22.06 .2020

Revision requested: 06.09 .2020

Last revision received: 15.07 .2020

Accepted: 17.09 .2020

Published online: 19.11.2020

Correspondence:

Serkan SAYGUN

E-mail: serkan_saygun@hotmail.com

\section{ABSTRACT}

In this study, the fish species inhabiting the Bolaman Stream drains to the Black Sea from the Fatsa coast (Ordu Province, Turkey) was reported for the first time. The study was caught out nonperiodically by sampling from seven stations in the Bolaman Stream between July 2017 and November 2018. Fish samples were captured with an electroshock device. With this study, it was determined that the fish fauna of the Bolaman Stream is represented by 10 species in five families (Acheilognothidae, Cyprinidae, Gobiidae, Leuciscidae, and Salmonidae). These species were as follows, respectively Rhodeus amarus, Barbus tauricus, Capoeta banarescui, Neogobius fluviatilis, Ponticola turani, Alburnus derjugini, Squalius cephalus, Vimba vimba, Alburnoides fasciatus, and Salmo coruhensis.

Keywords: Fish fauna, Fish taxonomy, New record, Inland waters

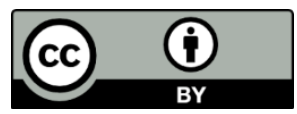

(C) 2021 The Author(s)

Available online at http://aquatres.scientificwebjournals.com 


\section{Introduction}

Since three-quarters of the world constitute an aquatic habitat, there is a continuous rise as a result of increasing scientific studies in the species number of fish having the fifty percentages of vertebrates. It was reported that this number has been 35672 by adding new species within the last quarter of 2020 (Fricke et al., 2020). In Turkey, the first ichthyo-faunistic study began in the first half of the nineteenth century by sending twenty marine species collected from Trabzon Province to British researcher (Abbot, 1835). In the last 15 years, it has been observed that the number of fish detected has increased from 236 (Kuru, 2004) to 384 (Çiçek et al., 2020) in Turkey. This number reached 391 with some recent additional records by Çiçek (2020), Kaya et al. (2020a; 2020b), and Kaya (2020). However, in another source, it was informed that this species number reached only 401 in freshwaters of Turkey (Froese and Pauly, 2019). Many studies in this area are still ongoing, and it is understood that Turkish inland waters have a potential for new species that have not yet been discovered. By redefining previously discovered fish species, species confusion is also being tried to be eliminated. There are many small streams of various sizes such as the Kurna, Tabakhane (Ünye), Çalış (Fatsa) Streams for, etc. in the Black Sea basin and have not been studied as ichthyofaunistic yet. The Bolaman stream in Ordu Province was one of them, also.

The Bolaman is a stream to flow into the Black Sea in the northern Turkish provinces of Ordu and Tokat. The stream was called Sidenus in antiquity. The Bolaman Stream rises in the Canik Mountains, a mountain range of the Pontic Mountains. The Bolaman stream continues its course to the north and pours into the Black Sea in the eastern of Fatsa (Anonymous, 2018).

In consider the other taxonomic studies conducted in a lake and several rivers in around Ordu province, in which have been Melet River, Ilıca and Yalıköy Streams, Gaga Lake, Turnasuyu Stream, Curi Stream, Elekçi Stream, Ilıca Stream and Tifi Brook (Turan et al., 2008; Darçın, 2014; Dönel and Y1lmaz, 2016; Bostanc1 et al., 2015; 2016; Y1lmaz, 2016; Saygun et al., 2017; Turan et al. 2017).

In this study, it was aimed to reveal actual taxonomic status of the fish species living in the Bolaman Stream.

\section{Material and Methods}

The study was carried out by sampling nonperiodically fish at seven sampling stations on the Bolaman Stream (Figure 1) between July 2017 and November 2018 as specified in the examined material section below. The Bolaman Stream initially flows along the provincial borders of Tokat and Ordu in a westerly direction. Later, it turns north and passes through the village of Zaferimilli in Ordu Province. It flows shortly afterward east past the city Aybastı. The Bolaman Stream then flows through the city Kabataş. Then the Gölköy Stream flows from the right into the stream. In Eleşi Brook meets the stream from the left (Anonymous, 2018). Detailed survey information (coordinates, altitudes, species, specimen quantity, and collection codes) of stations were listed in Table 1. At least five fish samples from each species were collected quarterly with an electroshock device (SAMUS ${ }^{\text {TM}}$-725MP). After sampling, the fish specimens were firstly anesthetized with oil of cloves and after stopping breath then stored within a 4\% formaldehyde solution in Fatsa Faculty of Marine Science (FFMS) of Ordu University (ODU) for species identification. Later, the meristic characters dorsal (D), pectoral (P), pelvic (V), and anal fin (A) ray numbers (spinous and branched rays) with lateral line (LL) scale counting were made. Lateral line scales were counts from the anteriormost scale (the first one to touch the shoulder girdle) to posteriormost one (at the end of the hypural joint) (Stoumboudi et al., 2006). Standard length (SL) was measured from the point of the snout to the end of the hypural joint (Stoumboudi et al., 2006). Head length (HL) was measured from the anteriormost part of the head (jaws closed) to the posteriormost point of the opercular bone, excluding spines and gills membrane (Holčík, 1989).

All the other morphometric characters changed from species to species were recorded in Microsoft Excel ${ }^{\mathrm{TM}}$ program by measuring digital caliper (Dasqua ${ }^{\mathrm{TM}}$ ) with $0.01 \mathrm{~mm}$ precision as methods reported by Holčík (1989). According to morphometric measurement results obtained from the study, the percentages of some metric characters of fish samples were calculated by proportioned of the standard length (SL\%) and by the head length (HL\%) for different fish families (Holčík, 1989; Bănărescu, 1999; Bănărescu and Bogutskaya, 2002; Bănărescu and Paepke, 2003; Miller, 2003; Verep et al., 2006; Turan et al., 2014; 2017). 


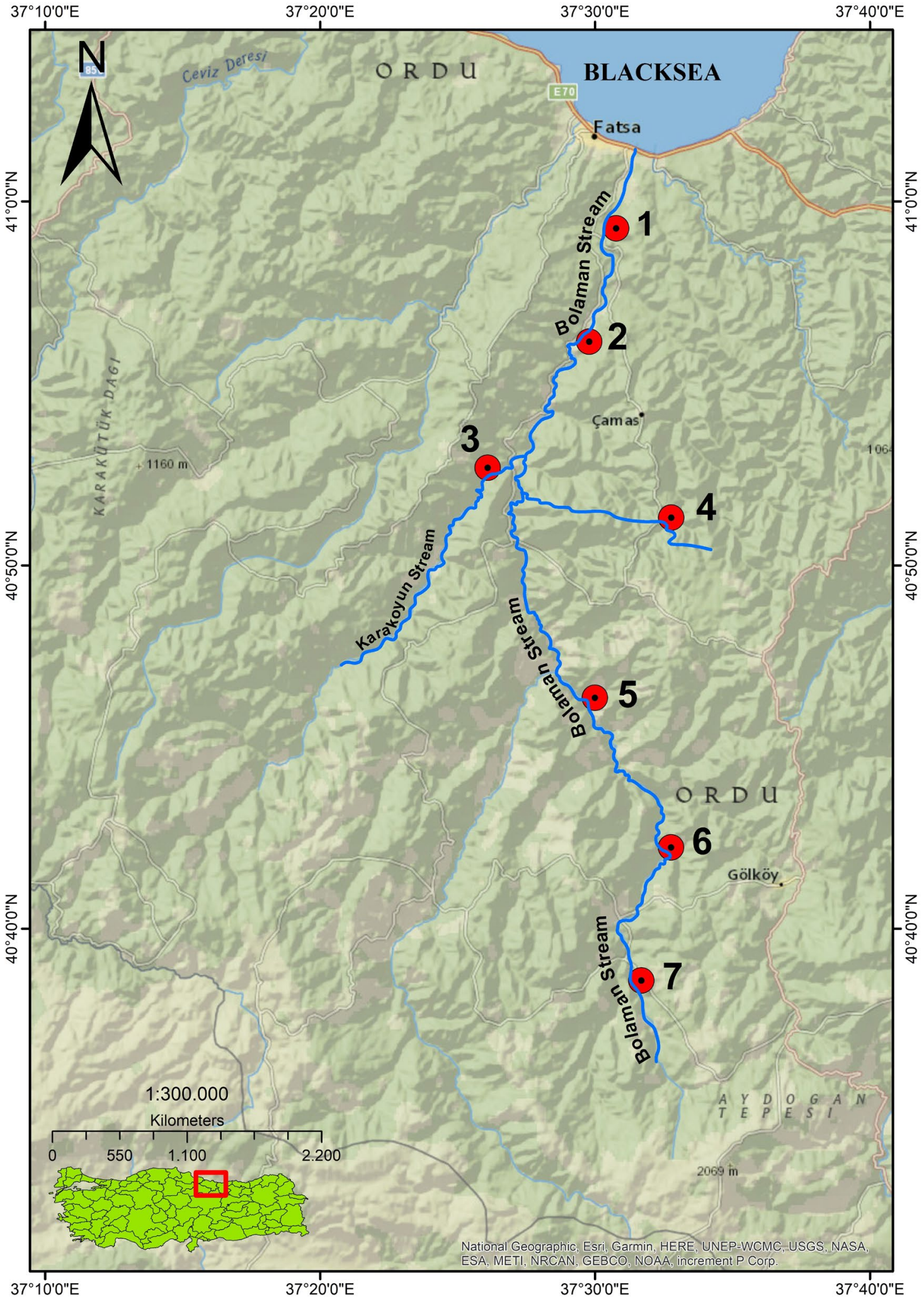

Figure 1. Fish sampling stations in the Bolaman Stream (Table 1) 
Table 1. Distribution of fish species as sampling stations in Bolaman Stream, sp: sampling points.

\begin{tabular}{|c|c|c|c|c|c|c|c|c|c|}
\hline \multirow{2}{*}{ sp } & \multirow{2}{*}{ Coordinates } & \multirow{2}{*}{$\begin{array}{l}\text { Altitudes } \\
(\mathbf{m})\end{array}$} & \multicolumn{6}{|c|}{ Species } & \multirow{2}{*}{$\begin{array}{c}\text { Sampling } \\
\text { Date } \\
\end{array}$} \\
\hline & & & $\mathbf{n}$ & Cyprinoids & $\mathbf{n}$ & Gobioids & $\mathbf{n}$ & Salmonids & \\
\hline 1 & $\begin{array}{l}40^{\circ} 59^{\prime} 15^{\prime \prime N} \\
37^{\circ} 29^{\prime} 55^{\prime \prime} \mathrm{E}\end{array}$ & 24 & $\begin{array}{c}2 \\
17 \\
5 \\
9 \\
\end{array}$ & $\begin{array}{l}\text { A. fasciatus } \\
\text { B. tauricus } \\
\text { C. banarescui } \\
\text { S. cephalus }\end{array}$ & $\begin{array}{c}2 \\
11\end{array}$ & $\begin{array}{l}\text { N. fluviatilis } \\
P . \text { turani }\end{array}$ & & - & 06.07 .2017 \\
\hline 2 & $\begin{array}{l}40^{\circ} 56^{\prime} 23^{\prime \prime} \mathrm{N} \\
37^{\circ} 29^{\prime} 32^{\prime \prime} \mathrm{E}\end{array}$ & 55 & $\begin{array}{c}1 \\
11 \\
23 \\
10 \\
4 \\
20 \\
5\end{array}$ & $\begin{array}{l}\text { A. fasciatus } \\
\text { A. derjugini } \\
\text { B. tauricus } \\
\text { C. banarescui } \\
\text { R. amarus } \\
\text { S. cephalus } \\
\text { V. vimba }\end{array}$ & $\begin{array}{c}2 \\
12\end{array}$ & $\begin{array}{l}\text { N. fluviatilis } \\
P . \text { turani }\end{array}$ & & - & 11.07 .2017 \\
\hline 3 & $\begin{array}{l}40^{\circ} 52^{\prime} 28^{\prime \prime} \mathrm{N} \\
37^{\circ} 26^{\prime} 01^{\prime \prime} \mathrm{E}\end{array}$ & 163 & $\begin{array}{c}5 \\
11 \\
3 \\
\end{array}$ & $\begin{array}{l}\text { C. banarescui } \\
\text { R. amarus } \\
\text { S. cephalus }\end{array}$ & $\begin{array}{l}4 \\
2\end{array}$ & $\begin{array}{l}\text { N. fluviatilis } \\
P . \text { turani }\end{array}$ & & - & 19.05 .2018 \\
\hline 4 & $\begin{array}{l}40^{\circ} 51^{\prime} 14 " \mathrm{~N} \\
37^{\circ} 32^{\prime} 47^{\prime \prime} \mathrm{E}\end{array}$ & 753 & 33 & C. banarescui & & - & 5 & S. coruhensis & 10.11 .2018 \\
\hline 5 & $\begin{array}{l}40^{\circ} 45^{\prime} 21^{\prime \prime} \mathrm{N} \\
37^{\circ} 30^{\prime} 38^{\prime \prime} \mathrm{E}\end{array}$ & 526 & $\begin{array}{c}1 \\
10 \\
4 \\
2 \\
3 \\
9 \\
\end{array}$ & $\begin{array}{l}\text { A. fasciatus } \\
\text { A. derjugini } \\
\text { B. tauricus } \\
\text { C. banarescui } \\
\text { R. amarus } \\
\text { S. cephalus }\end{array}$ & 10 & P. turani & & - & 30.06 .2018 \\
\hline 6 & $\begin{array}{l}40^{\circ} 42^{\prime} 01^{\prime \prime} \mathrm{N} \\
37^{\circ} 32^{\prime} 58^{\prime \prime} \mathrm{E}\end{array}$ & 710 & $\begin{array}{l}8 \\
6 \\
2 \\
5 \\
2 \\
\end{array}$ & $\begin{array}{l}\text { A. derjugini } \\
\text { B. tauricus } \\
\text { C. banarescui } \\
\text { R. amarus } \\
\text { S. cephalus }\end{array}$ & 4 & P. turani & & - & 30.07 .2018 \\
\hline 7 & $\begin{array}{l}40^{\circ} 38^{\prime} 16^{\prime \prime N} \\
37^{\circ} 23^{\prime} 10^{\prime \prime} \mathrm{E} \\
\end{array}$ & 772 & & & & Jo sample & & & 30.07 .2018 \\
\hline
\end{tabular}

\section{Results and Discussion}

As a result of the study, a total of 263 specimens of 10 species were sampled in six sampling points determined on the Bolaman Stream (Figure 2) but the seventh station because not come across to any fish species. The details of sampling stations, as well as the fish species discovered in each one of them, were presented in Table 1. There were described two species from Cyprinidae, a species from Acheilognothidae, four species Leuciscidae, two species from Gobiidae, and one species from Salmonidae in systematic order as follows. It was seen that cypriniform species were predominant as in other streams in the region and Ponticola turani, which is a Gobioidae species, was also observed to be dense (Figure 3).
When looked at Figure 2, the percentages of seven cypriniform species consisted of Cyprinidae, Acheilognothidae, and Leuciscidae were seen to be $81 \%$ (211 samples) of all specimens.

According to the sampling stations in the Bolaman Stream, all species, except Salmo coruhensis, were found in $2^{\text {nd }}$ station. Although all the stations of Capoeta banarescui were also encountered but seventh station, which allowed no fish species. Only two species identified in the fourth station which were $C$. banarescui and $S$. coruhensis (Table 1).

The average percent data calculated according to some morphometric values of the fish species obtained in the Bolaman Stream were represented in Tables 2, 3, and 4. In these tables, 
the values were computed in percentages proportion to different morphometric data of standard length (SL) and head length (HL) (for all species). However, means ( $\bar{x}$ ) of morphometric values percentage accounted standard deviations $( \pm)$ of unclassified samples and distribution range $(m-M)$ for each sample were given in the tables.

Table 2. Mean $(\bar{x})$ percentage values of some morphometric characteristics of Cypriniform species obtained from the Bolaman Stream according to standard length (SL) and head length (HL). \pm Standard deviation, $m$-M minimum-maximum values.

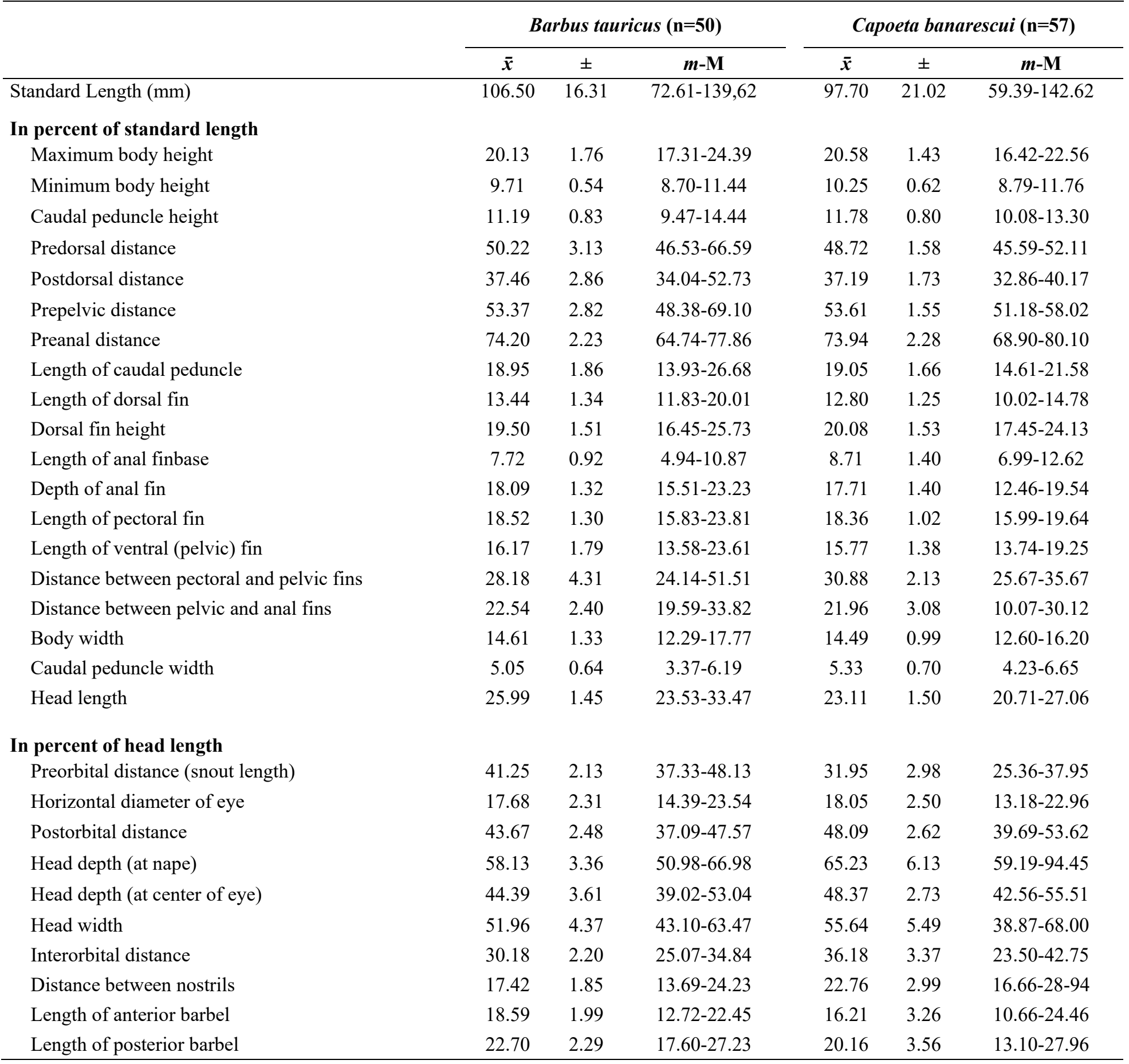


continuation of Table 2

\begin{tabular}{|c|c|c|c|}
\hline & \multicolumn{3}{|c|}{ Rhodeus amarus $(\mathrm{n}=23)$} \\
\hline & $\bar{x}$ & \pm & $m-\mathbf{M}$ \\
\hline Standard Length $(\mathrm{mm})$ & 106.50 & 16.31 & 72.61-139.62 \\
\hline \multicolumn{4}{|l|}{ In percent of standard length } \\
\hline Maximum body height & 21.73 & 1.21 & $19.04-23.69$ \\
\hline Minimum body height & 10.82 & 0.63 & $9.68-12.09$ \\
\hline Caudal peduncle height & 12.51 & 0.82 & $10.85-13.96$ \\
\hline Predorsal distance & 52.01 & 1.82 & $49.77-56.35$ \\
\hline Postdorsal distance & 36.77 & 2.07 & $31.50-39.74$ \\
\hline Prepelvic distance & 49.08 & 0.96 & $47.64-50.97$ \\
\hline Preanal distance & 70.64 & 4.40 & $67.08-87.50$ \\
\hline Length of caudal peduncle & 21.20 & 1.51 & $18.51-23.51$ \\
\hline Length of dorsal fin & 10.90 & 1.08 & $9.34-13.58$ \\
\hline Dorsal fin height & 18.30 & 1.46 & $15.74-20.98$ \\
\hline Length of anal finbase & 10.43 & 0.72 & $9.06-11.56$ \\
\hline Depth of anal fin & 15.90 & 0.85 & $13.80-17.11$ \\
\hline Length of pectoral fin & 17.04 & 1.16 & $14.38-19.18$ \\
\hline Length of ventral (pelvic) fin & 13.75 & 0.76 & $12.69-15.74$ \\
\hline Distance between pectoral and pelvic fins & 25.46 & 1.60 & $22.56-28.70$ \\
\hline Distance between pelvic and anal fins & 20.80 & 0.79 & $19.54-22.23$ \\
\hline Body width & 13.87 & 1.34 & $11.09-15.88$ \\
\hline Caudal peduncle width & 5.31 & 0.83 & $3.66-6.66$ \\
\hline Head length & 24.32 & 0.93 & $22.78-26.42$ \\
\hline \multicolumn{4}{|l|}{ In percent of head length } \\
\hline Preorbital distance (snout length) & 27.87 & 2.63 & $23.60-32.68$ \\
\hline Horizontal diameter of eye & 21.26 & 1.87 & $17.85-25.38$ \\
\hline Postorbital distance & 52.71 & 3.11 & $47.32-61.55$ \\
\hline Head depth (at nape) & 66.29 & 4.18 & $54.33-72.77$ \\
\hline Head depth (at center of eye) & 48.77 & 2.61 & $42.98-54.57$ \\
\hline Head width & 55.14 & 4.83 & $45.17-64.33$ \\
\hline Interorbital distance & 36.93 & 3.22 & $31.57-42.90$ \\
\hline Distance between nostrils & 21.45 & 2.56 & $16.24-27.68$ \\
\hline
\end{tabular}


continuation of Table 2

\begin{tabular}{|c|c|c|c|c|c|c|}
\hline & \multicolumn{3}{|c|}{ Alburnus derjugini $(\mathrm{n}=29)$} & \multicolumn{3}{|c|}{ Squalius cephalus $(\mathrm{n}=43)$} \\
\hline & $\overline{\boldsymbol{x}}$ & \pm & $m$-M & $\overline{\boldsymbol{x}}$ & \pm & $m-\mathbf{M}$ \\
\hline Standard Length (mm) & 102.79 & 15.84 & $62.24-133.19$ & 97.49 & 25.98 & $57.74-150.22$ \\
\hline \multicolumn{7}{|l|}{ In percent of standard length } \\
\hline Maximum body height & 19.98 & 0.95 & $17.43-21.77$ & 26.61 & 1.12 & $25.88-28.83$ \\
\hline Minimum body height & 8.08 & 0.42 & $7.30-8.97$ & 9.70 & 0.08 & $9.59-9.80$ \\
\hline Caudal peduncle height & 10.37 & 0.75 & $9.24-12.63$ & 11.52 & 0.72 & $10.51-12.40$ \\
\hline Predorsal distance & 52.63 & 6.73 & $20.40-56.88$ & 51.74 & 0.53 & $50.84-52.45$ \\
\hline Postdorsal distance & 35.34 & 1.75 & $32.86-40.30$ & 38.70 & 1.66 & $35.80-40.18$ \\
\hline Prepelvic distance & 46.12 & 1.31 & $43.09-48.43$ & 48.22 & 1.31 & $46.14-49.71$ \\
\hline Preanal distance & 64.82 & 2.01 & $60.86-70.23$ & 66.89 & 1.91 & $64.57-70.16$ \\
\hline Length of caudal peduncle & 21.21 & 1.47 & $18.06-23.72$ & 18.20 & 1.66 & $16.03-20.49$ \\
\hline Length of dorsal fin & 11.05 & 1.06 & $9.16-12.97$ & 12.22 & 0.53 & $11.36-12.91$ \\
\hline Dorsal fin height & 16.52 & 1.54 & 13.73-19.99 & 21.34 & 2.32 & $18.08-24.16$ \\
\hline Length of anal finbase & 15.69 & 1.17 & $13.44-17.64$ & 18.44 & 0.99 & $16.53-19.18$ \\
\hline Depth of anal fin & 12.36 & 1.32 & $10.13-15.24$ & 13.46 & 1.05 & $12.04-14.77$ \\
\hline Length of pectoral fin & 18.02 & 1.40 & $15.21-20.44$ & 18.07 & 0.98 & $16.80-19.36$ \\
\hline Length of ventral (pelvic) fin & 13.57 & 1.53 & 11.11-19.49 & 16.24 & 0.66 & $15.10-16.85$ \\
\hline Distance between pectoral and pelvic fins & 24.77 & 1.33 & $21.69-27.43$ & 21.52 & 0.91 & $19.77-22.42$ \\
\hline Distance between pelvic and anal fins & 18.94 & 1.13 & $16.79-21.67$ & 21.11 & 0.91 & $19.55-22.07$ \\
\hline Body width & 12.21 & 1.46 & $10.00-16.05$ & 12.86 & 0.88 & $11.56-13.86$ \\
\hline Caudal peduncle width & 5.06 & 0.54 & $4.08-6.13$ & 4.36 & 0.21 & $4.13-4.61$ \\
\hline Head length & 23.13 & 1.98 & 20.91-31.97 & 24.94 & 0.61 & $24.07-25.74$ \\
\hline \multicolumn{7}{|l|}{ In percent of head length } \\
\hline Preorbital distance (snout length) & 29.78 & 3.13 & $20.32-34.63$ & 31.47 & 2.75 & $28.79-35.39$ \\
\hline Horizontal diameter of eye & 25.55 & 3.35 & $18.43-31.75$ & 21.98 & 1.11 & $20.16-23.55$ \\
\hline Postorbital distance & 43.65 & 4.44 & $30.11-49.70$ & 46.43 & 2.42 & $42.85-49.61$ \\
\hline Head depth (at nape) & 63.73 & 5.24 & $44.66-73.64$ & 71.46 & 3.69 & $67.69-78.12$ \\
\hline Head depth (at center of eye) & 47.65 & 4.08 & $35.50-54.81$ & 53.06 & 2.65 & $50.58-56.89$ \\
\hline Head width & 45.61 & 3.56 & $31.75-49.05$ & 48.34 & 1.08 & $46.49-49.39$ \\
\hline Interorbital distance & 28.78 & 3.59 & $20.94-40.58$ & 31.86 & 2.33 & $29.46-35.77$ \\
\hline Distance between nostrils & 14.48 & 2.51 & $8.69-19.94$ & 17.25 & 1.09 & $15.72-18.25$ \\
\hline
\end{tabular}


continuation of Table 2

\begin{tabular}{|c|c|c|c|c|c|c|}
\hline & \multicolumn{3}{|c|}{ Vimba vimba $(\mathrm{n}=5)$} & \multicolumn{3}{|c|}{ Alburnoides fasciatus $(n=4)$} \\
\hline & $\overline{\boldsymbol{x}}$ & \pm & $m$-M & $\overline{\bar{x}}$ & \pm & $m$-M \\
\hline Standard Length (mm) & 115.86 & 5.26 & $105.75-120.23$ & 67.39 & 1.77 & $64.41-69.06$ \\
\hline \multicolumn{7}{|l|}{ In percent of standard length } \\
\hline Maximum body height & 26.61 & 1.12 & $19.04-23.69$ & 20.47 & 0.88 & $19.15-21.47$ \\
\hline Minimum body height & 9.70 & 0.08 & $9.68-12.09$ & 8.25 & 0.26 & $7.90-8.57$ \\
\hline Caudal peduncle height & 11.52 & 0.72 & $10.85-13.96$ & 9.77 & 0.37 & $9.18-10.11$ \\
\hline Predorsal distance & 51.74 & 0.53 & $49.77-56.35$ & 42.67 & 2.07 & $41.28-46.24$ \\
\hline Postdorsal distance & 38.70 & 1.66 & $31.50-39.74$ & 29.88 & 1.29 & $28.19-31.73$ \\
\hline Prepelvic distance & 48.22 & 1.31 & $47.64-50.97$ & 39.20 & 2.03 & $36.80-42.41$ \\
\hline Preanal distance & 66.89 & 1.91 & $67.08-87.50$ & 17.43 & 0.76 & $16.17-18.10$ \\
\hline Length of caudal peduncle & 18.20 & 1.66 & $18.51-23.51$ & 16.05 & 0.49 & $15.65-16.89$ \\
\hline Length of dorsal fin & 12.22 & 0.53 & $9.34-13.58$ & 11.93 & 1.17 & $10.53-13.76$ \\
\hline Dorsal fin height & 21.34 & 2.32 & $15.74-20.98$ & 17.11 & 3.28 & $11.96-21.04$ \\
\hline Length of anal finbase & 18.44 & 0.99 & $9.06-11.56$ & 14.98 & 2.08 & $11.78-17.13$ \\
\hline Depth of anal fin & 13.46 & 1.05 & $13.80-17.11$ & 14.38 & 1.41 & $12.45-16.08$ \\
\hline Length of pectoral fin & 18.07 & 0.98 & $14.38-19.18$ & 17.43 & 0.76 & $16.17-18.10$ \\
\hline Length of ventral (pelvic) fin & 16.24 & 0.66 & $12.69-15.74$ & 14.63 & 0.59 & $13.65-15.21$ \\
\hline Distance between pectoral and pelvic fins & 21.52 & 0.91 & $22.56-28.70$ & 20.11 & 0.84 & $18.79-21.07$ \\
\hline Distance between pelvic and anal fins & 21.11 & 0.91 & $19.54-22.23$ & 16.99 & 2.26 & $14.39-20.58$ \\
\hline Body width & 12.86 & 0.88 & $11.09-15.88$ & 10.31 & 0.37 & $9.90-10.86$ \\
\hline Caudal peduncle width & 4.36 & 0.21 & $3.66-6.66$ & 4.59 & 0.37 & $4.08-5.11$ \\
\hline Head length & 24.94 & 0.61 & $22.78-26.42$ & 20.06 & 0.17 & $19.89-20.34$ \\
\hline \multicolumn{7}{|l|}{ In percent of head length } \\
\hline Preorbital distance (snout length) & 31.47 & 2.75 & $23.60-32.68$ & 26.95 & 2.66 & $23.13-29.56$ \\
\hline Horizontal diameter of eye & 21.98 & 1.11 & $17.85-25.38$ & 27.49 & 3.05 & $22.35-30.04$ \\
\hline Postorbital distance & 46.43 & 2.42 & $47.32-61.55$ & 46.32 & 2.16 & $42.63-48.12$ \\
\hline Head depth (at nape) & 71.46 & 3.69 & $54.33-72.77$ & 73.54 & 1.72 & $71.88-76.38$ \\
\hline Head depth (at center of eye) & 53.06 & 2.65 & $42.98-54.57$ & 55.40 & 3.80 & $51.39-61.54$ \\
\hline Head width & 48.34 & 1.08 & $45.17-64.33$ & 47.35 & 3.28 & $44.98-52.94$ \\
\hline Interorbital distance & 31.86 & 2.33 & $31.57-42.90$ & 34.03 & 3.46 & $31.14-39.93$ \\
\hline Distance between nostrils & 17.25 & 1.09 & $16.24-27.68$ & 15.92 & 2.42 & $13.09-19.78$ \\
\hline
\end{tabular}




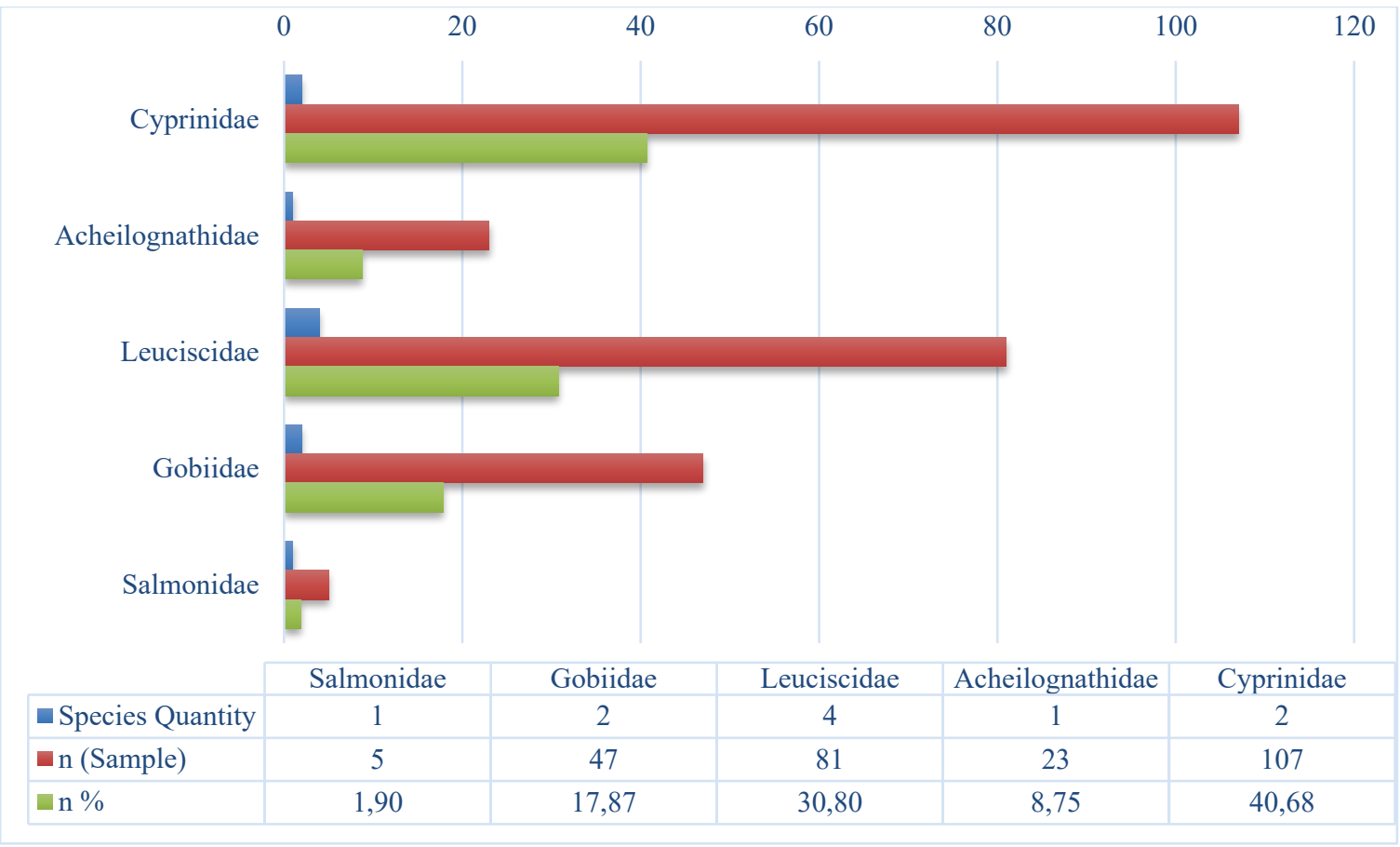

Figure 2. Families' distribution of Bolaman Stream according to specimen quantity

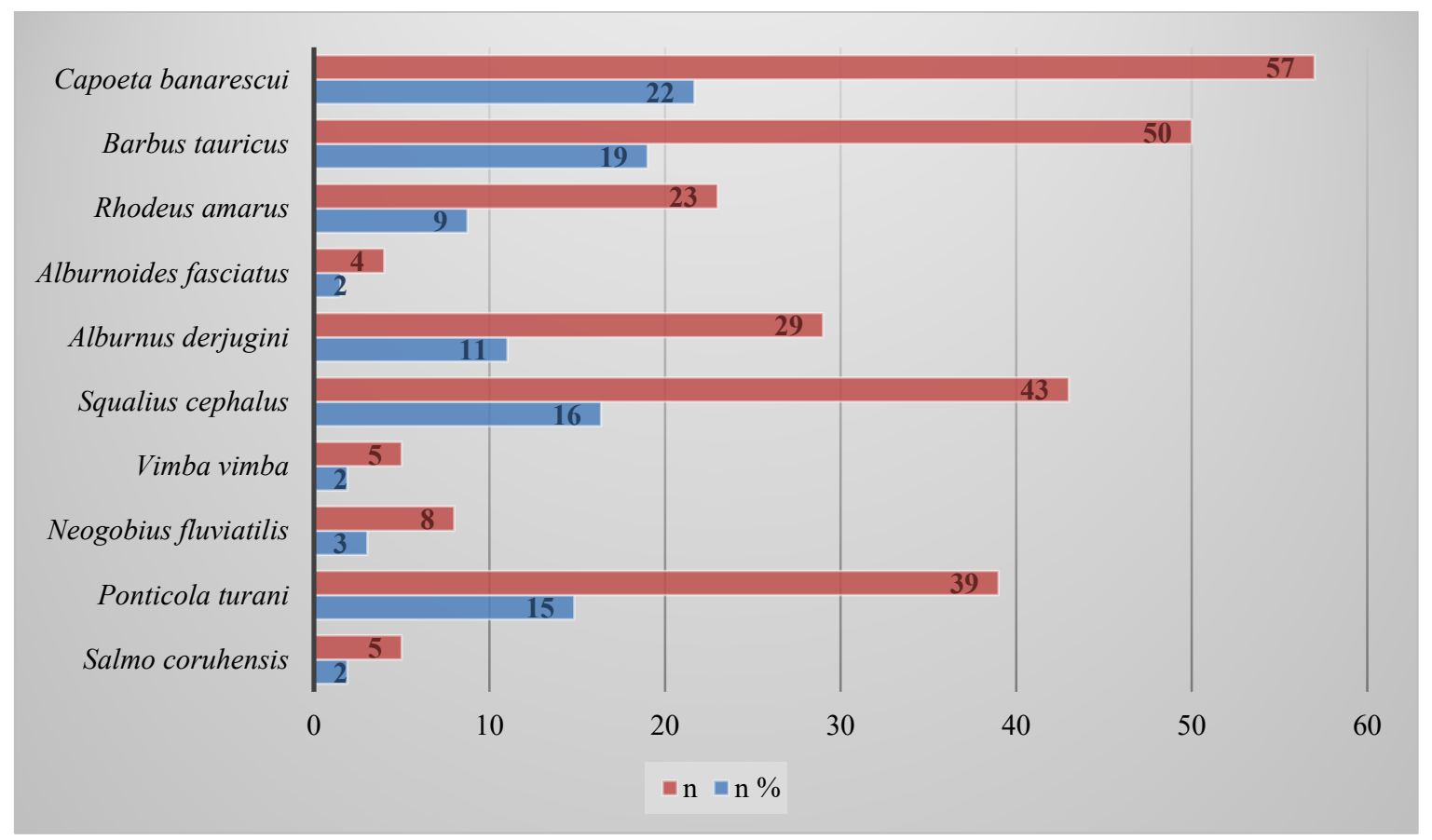

Figure 3. Number of samples (n) and percentage ratios (n \%) of fish species obtained from Bolaman Stream 


\section{Family: Cyprinidae}

\section{Capoeta banarescui Turan, Kottelat, Ekmekçi \& Imamo-} ğlu, 2006 (Figure 4)

Examined Material. ODUFFMS 52410-06040, 5, 59.39$142.62 \mathrm{~mm}$ SL; Turkey: Karataş, Fatsa/Ordu: Bolaman Stream; S. Saygun, 06 Jul 2017. - ODUFFMS 52410-06041, 10, 83.52-123.74 mm SL; Örencik, Fatsa/Ordu: Bolaman Stream; S. Saygun, 11 Jul 2017. - ODUFFMS 52420-06042, 5, 98.09-122.40 mm SL; Dere, Çatalpınar/Ordu: Karakoyun Stream; S. Saygun, 19 May 2018. - ODUFFMS 5243006043, 33, 70.82-100.98 mm SL; Kestaneyokuşu, Çamaş/Ordu: Bolaman Stream; S. Saygun, 10 Nov 2018. ODUFFMS 52600-06044, 2, 115.65-116.52 mm SL; Direkli, Gölköy/Ordu: Bolaman Stream; S. Saygun, 30 Jun 2018. ODUFFMS 52600-06045, 2, 81.37-122.43 mm SL; Çetilli, Gölköy/Ordu: Bolaman Stream; S. Saygun, 30 Jul 2018.

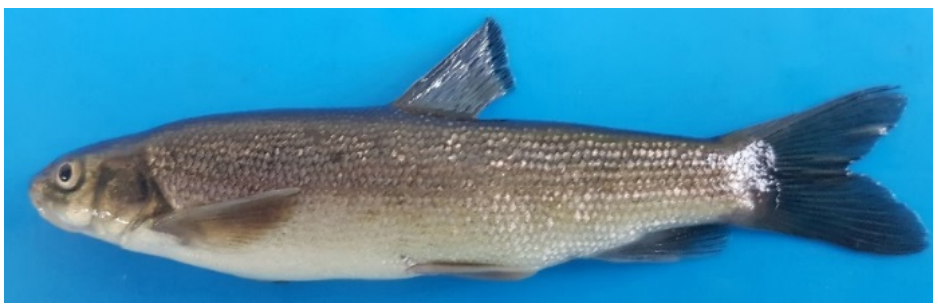

Figure 4. Capoeta banarescui, ODUFFMS 52410-06040, 142.62 mm SL; Turkey: Bolaman Stream

Capoeta banarescui including in Cyprinidae is known as one of the widely resident species in Turkish freshwaters through The Middle and East Blacksea Regions. Their distributions are only accepted from northeast Turkey from the Çoruh River system, which drains through Georgia and the Black Sea. Turan et al. (2006) reported that it was a different species from Capoeta tinca. In the study, C. banarescui was obtained at every stations except two sampling points as the second most common Cyprinoid species in the Bolaman Stream. The meristic characters of this barbel fish were designated as D I/7-8, A I/12-14, P I/14-15, V I/8 and LL 65-69. Morphometric ratios percent were shown in Table 2 .

\section{Barbus tauricus Kessler, 1877 (Figure 5)}

Examined Material. ODUFFMS 52410-06030, 17, 72.61$139.62 \mathrm{~mm}$ SL; Turkey: Karataş, Fatsa/Ordu: Bolaman Stream; S. Saygun, 06 Jul 2017. - ODUFFMS 52410-06031, 23, 83.85-129.15 mm SL; Örencik, Fatsa/Ordu: Bolaman Stream; S. Saygun, 11 Jul 2017. - ODUFFMS 52600-06032, 4, 76.92-127.27 mm SL; Direkli, Gölköy/Ordu: Bolaman Stream; S. Saygun, 10 Nov 2018. - ODUFFMS 5260006033, 6, 88.39-125.70 mm SL; Çetilli, Gölköy/Ordu: Bolaman Stream; S. Saygun, 30 Jun 2018.
Barbus tauricus is a barbel fish and the second most common species of cyprinoids in the Bolaman Stream. Results of morphometric measurement ratios percent procured from forty specimens of Crimean barbell were presented in Table 2. As the numerical counts of meristic characters were fixed to be D I/9, P I/8-9, V I/7-8, A I/5 and LL 50-58.

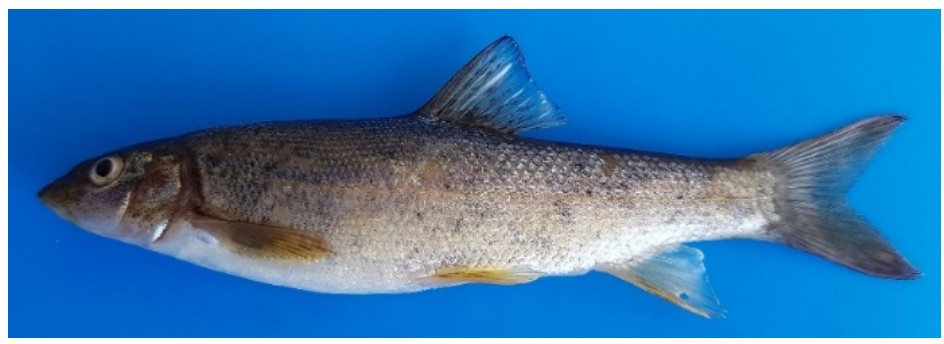

Figure 5. Barbus tauricus, ODUFFMS 52410-06030, 95.67 mm SL; Turkey: Bolaman Stream

\section{Family: Acheilognothidae}

\section{Rhodeus amarus (Bloch, 1872) (Figure 6)}

Examined Material. ODUFFMS 52410-06070, 4, 47.30$57.06 \mathrm{~mm}$ SL; Örencik, Fatsa/Ordu: Bolaman Stream; S. Saygun, 11 Jul 2017. - ODUFFMS 52430-06071, 11, 40.39$61.28 \mathrm{~mm}$ SL; Dere, Çatalpınar/Ordu: Karakoyun Stream; S. Saygun, 19 May 2018. - ODUFFMS 52600-06072, 3, 42.4846.05 SL; Direkli, Gölköy/Ordu: Bolaman Stream; S. Saygun, 30 Jun 2018. - ODUFFMS 52600-06073, 1, 36.2260.16 mm SL; Çetilli, Gölköy/Ordu: Bolaman Stream; S. Saygun, 30 Jul 2018.

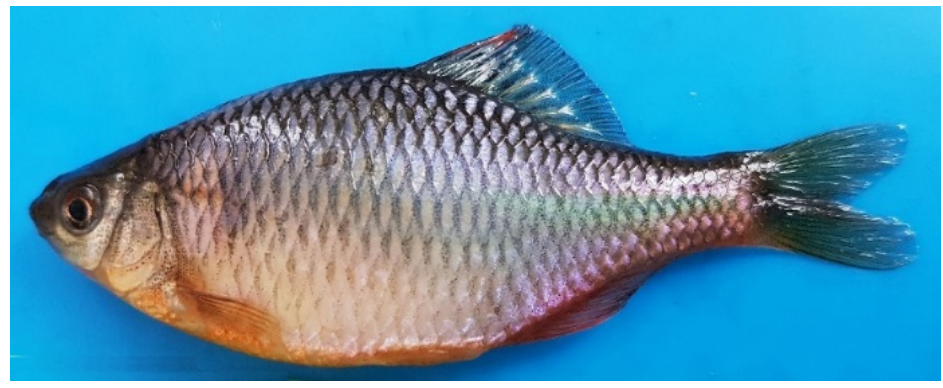

Figure 6. Rhodeus amarus, ODUFFMS 52410-06070, 55.28 mm SL; Turkey: Bolaman Stream

The European bitterling (Rhodeus amarus) originates in Europe, ranging from the Rhone River basin in France to the Neva River in Russia. It was originally described as Cyprinus amarus by Marcus Elieser Bloch in 1782 and has been referred to in scientific literature as Rhodeus sericeus amarus (Kottelat \& Freyhof, 2007). However, while it was previously estimated to found a subspecies of Rhodeus sericeus in Turkey's freshwaters, $R$. amarus was determined to be only one 
species belonging to Acheilognothidae (Tan and Armbruster, 2018) family in Turkey (Bektaş et al., 2013).

In this study, 23 European Bitterling specimens were caught at four stations $\left(2^{\text {nd }}, 3^{\text {rd }}, 5^{\text {th }}\right.$, and $6^{\text {th }}$ stations $)$ at the Bolaman Stream (Table 1). Results of the morphometric percent ratios of these specimens were represented in Table 2. Looking at meristic specialties being the other characters of bitterling, were counted that D I/8-9, A I/8-9, P I/6-8, V I/6 and LL 3538 in the research.

\section{Family: Leuciscidae}

\section{Alburnoides fasciatus (Nordmann, 1840) (Figure 7)}

Examined Material. ODUFFMS 52410-06010, 2, 52.48$56.11 \mathrm{~mm}$ SL, Turkey: Karataş, Fatsa/Ordu: Bolaman Stream; S. Saygun, 06 Jul 2017. - ODUFFMS 52420-06011, 1, 57.66 mm SL; Örencik, Fatsa/Ordu: Bolaman Stream; S. Saygun, 11 Jul 2017. - ODUFFMS 52600-06012, 1, 56.07 mm SL; Direkli, Gölköy/Ordu: Bolaman Stream; S. Saygun, 30 Jun 2018.

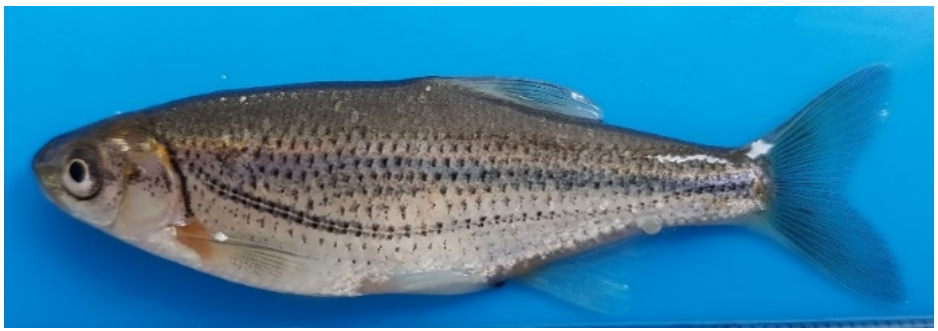

Figure 7. Alburnoides fasciatus, ODUFFMS 5241006010, $56.11 \mathrm{~mm}$ SL; Turkey: Bolaman Stream

In the study, the Transcaucasian Sprilin, Alburnoides fasciatus was obtained the least number of the sample with four specimens from the Bolaman Stream. Morphometric percent ratios of $A$. fasciatus samples was shown in Table 2 . The meristic characters of this species were determined D I/8-9, A I/12-14, P I/11-12, V I/7 and LL 42-45.

\section{Alburnus derjugini Berg, 1923 (Figure 8)}

Examined Material. ODUFFMS 52410-06020, 11, 91.12$101.54 \mathrm{~mm}$ SL; Örencik, Fatsa/Ordu: Bolaman Stream; S. Saygun, 11 Jul 2017. - ODUFFMS 52420-06021, 8, 95.85$128.94 \mathrm{~mm}$ SL; Dere, Çatalpınar/Ordu: Karakoyun Stream; S. Saygun, 19 May 2018. - ODUFFMS 52600-06022, 10, 62.24-133.19 mm SL; Direkli, Gölköy/Ordu: Bolaman Stream; S. Saygun, 30 Jun 2018.

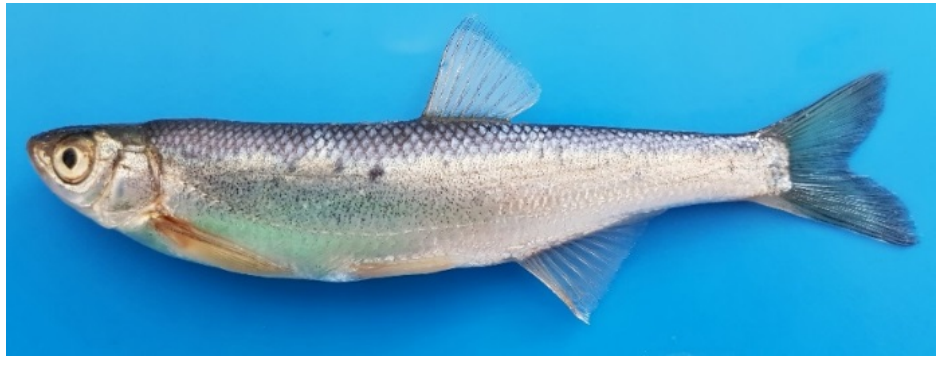

Figure 8. Alburnus derjugini, ODUFFMS 52410-06020, $98.05 \mathrm{~mm}$ SL; Turkey: Bolaman Stream

The Georgian shemaya (Alburnus derjugini), a species of Cyprinoid fish in the genus Alburnus and collected also in the Bolaman Stream, distributed in eastern Black Sea tributaries, from south of the Caucasus in Russia and Georgia, to the south the Çoruh River in eastern Anatolia and to the west the Sakarya River (Freyhof, 2014). According to the latest published molecular phylogenetic study (Bektaș et al., 2020), A. derjugini was determined that synonymized species of $A$. istanbulensis, A. carinatus and A. schischkovi.

A. derjugini was one of the common cyprinoid species in the Bolaman Stream and had an 11\% ratio into total fish samples in a rank of fourth (Figure 3). The countable characters of Georgian Shemaya were defined being D I/8, A I/13-14, P I/12-13, V I/8 and LL 57-60. Percent ratios as to metric measurements of 27 samples from the Bolaman Stream were represented in Table 2.

\section{Squalius cephalus (Linneaus, 1758) (Figure 9)}

Examined Material. ODUFFMS 52410-06090, 9, 57.74$150.22 \mathrm{~mm}$ SL; Turkey: Karataş, Fatsa/Ordu: Bolaman Stream; S. Saygun, 06 Jul 2017. - ODUFFMS 52410-06091, 20, 65.65-138.14 mm SL; Örencik, Fatsa/Ordu: Bolaman Stream; S. Saygun, 11 Jul 2017. - ODUFFMS 52420-06092, 3, 113.97-121.49 mm SL; Dere, Çatalpınar/Ordu: Karakoyun Stream; S. Saygun, 19 May 2018. - ODUFFMS 5260006093, 9, 74.02-118.80 mm SL; Direkli, Gölköy/Ordu: Bolaman Stream; S. Saygun, 30 Jun 2018. - ODUFFMS 5260006094, 2, 79.02-118.65 mm SL; Çetilli, Gölköy/Ordu: Bolaman Stream; S. Saygun, 30 Jul 2018. 


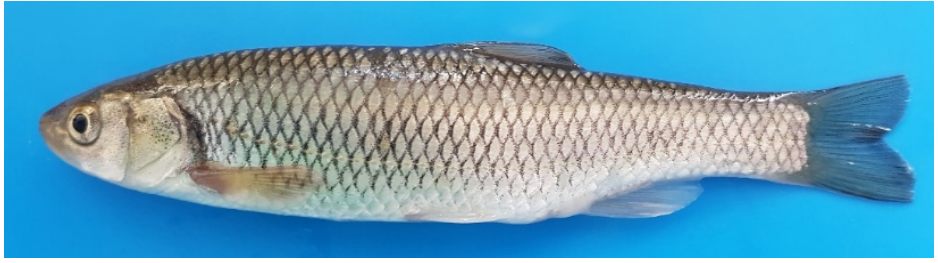

Figure 9. Squalius cephalus, ODUFFMS 52410-06090, 150.22 mm SL; Turkey: Bolaman Stream

The Squalius living from the rivers of the European and eastern Black Sea are usually identified as $S$. cephalus (Kottelat and Freyhof, 2007). S. orientalis is available for the 'Eastern' lineage while they temporarily use $S$. cephalus for the 'Western' lineage (Özuluğ and Freyhof, 2011). Squalius sampled in our study indicated that it belongs to the Western lineages. Squalius cephalus (Chub) sample shown in Figure 9 was one of the 43 samples procured from the Bolaman Stream. In the Table 2, morphometric ratios percent of this species were shown. The meristic results were detected D I/8, A I/8, P I/1213, V I/7-8 and LL 42-44.

\section{Vimba vimba (Linnaeus, 1758) (Figure 10)}

Examined Material. ODUFFMS 52410-06100, 5, 105.75$120.23 \mathrm{~mm}$ SL; Örencik, Fatsa/Ordu: Bolaman Stream; S. Saygun, 11 Jul 2017.

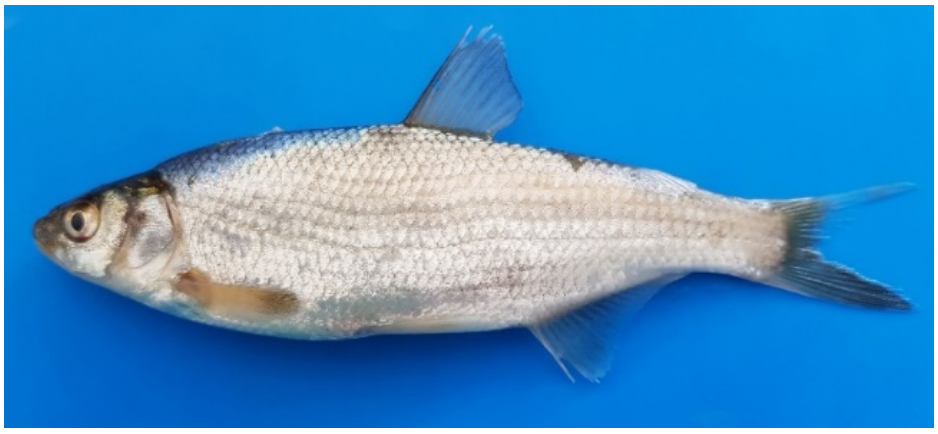

Figure 10. Vimba vimba, ODUFFMS 52410-06100, 120.13 mm SL; Turkey: Bolaman Stream

Vimba vimba species was one of the two species that collected the minimum number in the Bolaman Stream. Five specimens captured from the only the second station was measured and counted some metric characters. The counting characters were found D I/8, A I/13-14, P I/13-14, V I/8 and LL 50-54. Looking at the Table 2, the percentages of morphometric measurements ratios were given in this species.

\section{Family: Gobiidae}

Neogobius fluviatilis (Pallas, 1814) (Figure 11)

Examined Material. ODUFFMS 52450-06040, 2, 82.55$94.24 \mathrm{~mm}$ SL; Turkey: Karataş, Fatsa/Ordu: Bolaman
Stream; S. Saygun, 06 Jul 2017. - ODUFFMS 52410-06051, 2, 88.96-106.72 mm SL; Örencik, Fatsa/Ordu: Bolaman Stream; S. Saygun, 11 Jul 2017. - ODUFFMS 52420-06052, 4, 59.56-105.93 mm SL; Dere, Çatalpınar/Ordu: Karakoyun Stream; S. Saygun, 19 May 2018.

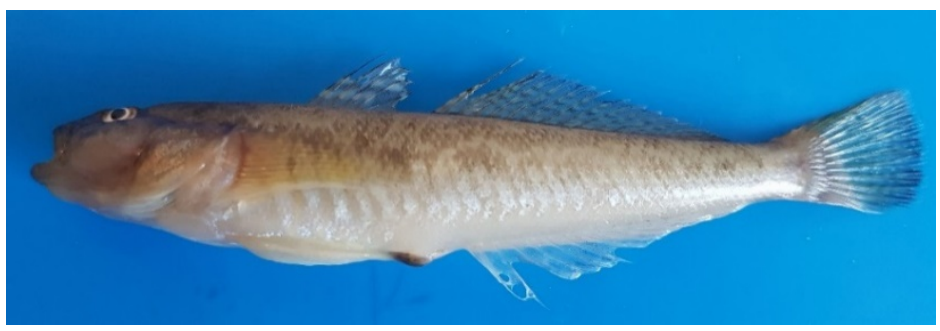

Figure 11. Neogobius fluviatilis, ODUFFMS 52410-06050, 94.24 mm SL; Turkey: Bolaman Stream

Neogobius fluviatilis shown a specimen in Figure 11 were sampled eight specimens in the Bolaman Stream in this study. It was counted and measured their meristic and metric characters of Monkey goby specimens. The meristic characters were indicated to be D1 V, D2 14-18, A I/13-14, LL 66-69. In the Table 3, morphometric percent ratios of this species were shown.

\section{Ponticola turani (Kovačić \& Engin, 2008) (Figure 12)}

Examined Material. ODUFFMS 52410-06060, 11, 79.32$111.09 \mathrm{~mm}$ SL; Turkey: Karataş, Fatsa/Ordu: Bolaman Stream; S. Saygun, 06 Jul 2017. - ODUFFMS 52410-06061, 12, 84.35-108.18 mm SL; Örencik, Fatsa/Ordu: Bolaman Stream; S. Saygun, 11 Jul 2017. - ODUFFMS 52420-06062, 2, 67.67-91.32 mm SL; Dere, Çatalpınar/Ordu: Karakoyun Stream; S. Saygun, 19 May 2018. - ODUFFMS 5260006063, 10, 77.00-110.98 mm SL; Direkli, Gölköy/Ordu: Bolaman Stream; S. Saygun, 30 Jun 2018. - ODUFFMS 5260006064, 4, 67.94-91.89 mm SL; Çetilli, Gölköy/Ordu: Bolaman Stream; S. Saygun, 30 Jul 2018.

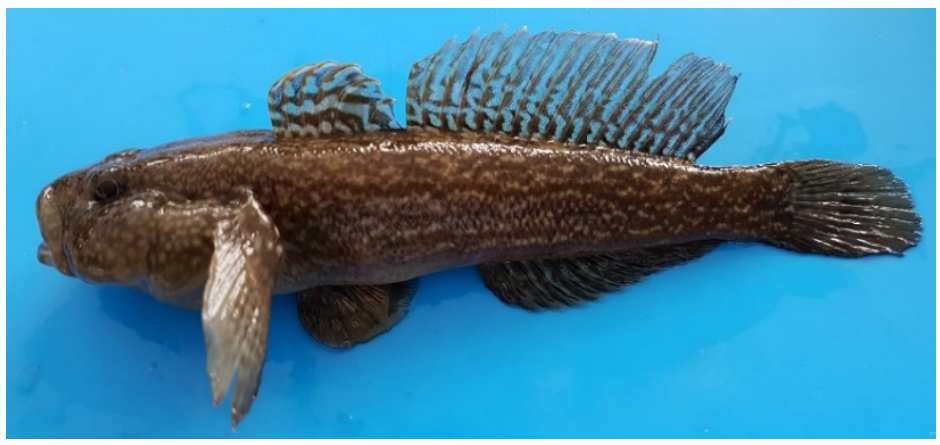

Figure 12. Ponticola turani, ODUFFMS 52410-06060, 111.09 mm SL; Turkey: Bolaman Stream 
Aksu goby, one of the endemic species of Turkey, was the fourth most caught species in the Bolaman Stream (Figure 3). Percent ratios as to metric measurements of specimens from the Bolaman Stream were represented in Table 3. Countable characters were found to be D1 VI, D2 15-16, A I/11-14, LL 60-65.

\section{Family: Salmonidae}

\section{Salmo coruhensis Turan, Kottelat \& Engin, 2010 (Figure 13)}

Examined Material. ODUFFMS 52430-06080, 5, 116.94$230.50 \mathrm{~mm}$ SL; Kestaneyokuşu, Çamaş/Ordu: Bolaman Stream; S. Saygun, 10 Nov 2018.

The Çoruh trout, one of the endemic species in North inland waters of Turkey, was observed in this study, too. Salmo coruhensis, which is living commonly in cold streams of Eastern Black Sea in Turkey and which is described as a new endemic species by Turan et al. (2009), is still accepted as a valid species in taxonomic literature but, in a molecular study performed by Kalayc1 et al. (2018) it was reported that this species and similar salmonid species are from the Danube lineage of brown trout (Salmo trutta). S. coruhensis, which naturally lives in higher places compared to other species, has also been found at approx. $753 \mathrm{~m}$ altitude (Table 1) of the stream in this study. In the seventh station, the highest sampling point, it was unbelievable not to come across neither salmonids nor any fish species. The meristic data were counted D I/10-12, A I/9-10, P I/12, V I/8-9 and LL 87-90.

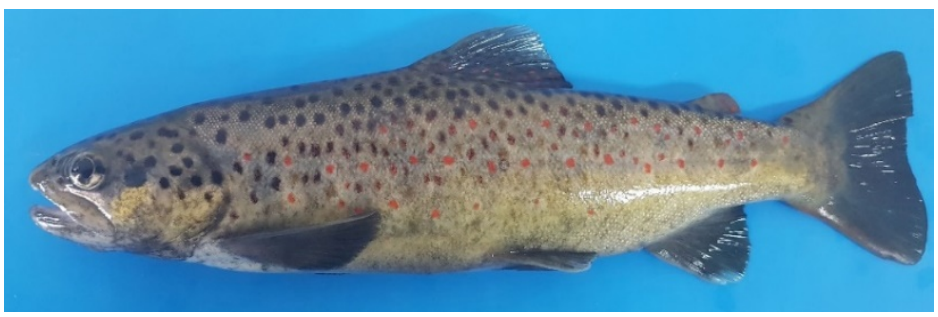

Figure 13. Salmo coruhensis, ODUFFMS 52430-06080, $230.50 \mathrm{~mm}$ SL; Turkey: Bolaman Stream

Some morphometric characters of $S$. coruhensis specimens were accounted for as a percentage ratio according to standard length (SL) and head length (HL). Morphometric percentage ratios of this species were shown in Table 4.

\section{Conclusion}

In this study, the number of species in the Bolaman Stream was also the highest in the Cyprinoid species with about $80 \%$ (211 samples), but the Barbus and Capoeta species were approx. $41 \%$ of the total sample number (Figure 2). According to the distribution of fish species in the stream, the least intense sampled species were about $2 \%$ of Alburnoides fasciatus, Salmo coruhensis and Vimba vimba. The Ponticola turani (approx. 15\%) was the most common forth species after C. banarecui, B. tauricus and $S$. cephalus. As a single species, Salmo coruhensis from Salmonidae family and Rhodeus amarus species from Acheilognothidae family were obtained. However, when the distribution in stations of the samples obtained in the study was examined, the second station (nine species) has the highest number of species compared to other sampling points.

Squalius cephalus and $S$. orientalis are two species that are similar to each other and have been difficulty distinguished. Berg (1949) had identified $S$. cephalus from $S$. orientalis (as subspecies of $S$. cephalus) by the number of branched analfin rays (usually $8^{1 / 2}$ in $S$. cephalus vs. usually $9^{1 / 2}$ in $S$. orientalis) and body shape (body more elongate in S. orientalis) (Özulug and Freyhof, 2011). 95\% of the 43 samples (ODUFFMS 52410-06090) obtained in this study had the specified feature which are quite elongate and have all $8^{1 / 2}$ branched anal-fin rays.

As the conclusion of this study, for the first time, it was identified ten species in five different genera belonging to five families (Acheilognothidae, Cyprinidae, Gobiidae, Leuciscidae, and Salmonidae) in the Bolaman Stream. During the sampling performed, it was seen that there is pollution in sections, which also is less the water than the main riverbed and even in the high parts of the stream. Moreover, it was determined that there are few or no species at some stations, where environmental conditions threaten the habitats of the fish in the research. According to data obtained from samplings conducted in the study during the summer months, the Hydroelectric Power Plants founded on the Bolaman Stream have been observed that been threaten enough water regime for the survival of fish. Contrary to what I expect in this study, it is possible to say that environmental conditions threaten the habitat of fishes along the stream as a result of taking more fish samples of different species from small streams that flow into the Bolaman Stream and are relatively cleaner than the stream. The fact that no samples of any species were not obtained from a station $\left(7^{\text {th }}\right.$ st) on one of the highest elevations can be also an indication of this. Monitoring of changes threatening the future of fauna and flora in the stream and more detailed physicochemical and taxonomic studies are needed within or after a decade. 
Table 3. Mean $(\bar{x})$ percentage ratios of some morphometric characters of Gobioid species obtained from the Bolaman Stream according to standard length and head length. \pm Standard deviation, $m$-M minimum-maximum values

\begin{tabular}{|c|c|c|c|c|c|c|}
\hline & \multicolumn{3}{|c|}{ Neogobius fluviatilis $(\mathrm{n}=8)$} & \multicolumn{3}{|c|}{ Ponticola turani $(\mathrm{n}=39)$} \\
\hline & $\bar{x}$ & \pm & $m-\mathbf{M}$ & $\overline{\boldsymbol{x}}$ & \pm & $m$-M \\
\hline Standard Length $(\mathrm{mm})$ & 83.46 & 17.68 & 59.56-106.72 & 93.35 & 11.33 & $67.67-111.09$ \\
\hline \multicolumn{7}{|l|}{ In percent of standard length } \\
\hline Length of head & 26.84 & 0.82 & $25.78-28.39$ & 27.50 & 1.66 & $22.01-30.14$ \\
\hline Head depth (at nape) & 15.27 & 1.36 & $13.48-17.13$ & 18.16 & 2.13 & $13.61-24.59$ \\
\hline Predorsal distance 1 & 31.84 & 1.46 & $29.67-34.13$ & 32.71 & 3.09 & $27.53-48.80$ \\
\hline Predorsal distance 2 & 46.34 & 2.83 & $39.83-49.50$ & 47.37 & 1.68 & $43.88-50.93$ \\
\hline Pength of dorsal fin 2 & 40.30 & 1.10 & $37.73-41.73$ & 46.25 & 2.50 & $38.36-51.72$ \\
\hline Dorsal fin heigth2 & 13.76 & 1.57 & 11.48-17.06 & 29.40 & 3.60 & $22.50-41.84$ \\
\hline Length of pectoral fin & 23.14 & 2.39 & $19.17-27.37$ & 21.82 & 2.87 & $11.55-29.16$ \\
\hline Length of pelvic fin & 19.20 & 1.82 & $16.19-21.90$ & 16.45 & 1.18 & $14.17-18.79$ \\
\hline Length of anal finbase & 30.95 & 2.45 & $26.82-35.63$ & 27.42 & 1.76 & $23.04-31.03$ \\
\hline Length of caudal peduncle & 18.23 & 1.62 & $15.81-20.69$ & 17.78 & 2.33 & $12.90-22.74$ \\
\hline Minimum body height & 7.02 & 0.26 & $6.53-7.37$ & 9.56 & 0.56 & $8.40-10.60$ \\
\hline Maximum body height & 17.06 & 1.40 & $14.52-19.11$ & 19.98 & 1.33 & $16.19-22.52$ \\
\hline Head width & 17.19 & 2.08 & $15.21-22.07$ & 21.58 & 1.73 & $18.24-25.44$ \\
\hline \multicolumn{7}{|l|}{ In percent of head length } \\
\hline Preorbital distance & 35.21 & 1.56 & $33.90-39.13$ & 32.05 & 5.03 & $22.88-48.68$ \\
\hline Horizontal diameter of eye & 17.74 & 1.75 & $14.84-21.32$ & 19.31 & 2.15 & $15.23-24.01$ \\
\hline Postorbital distance & 50.18 & 2.82 & $46.17-54.67$ & 52.18 & 6.16 & $41.65-74.13$ \\
\hline Head depth (at nape) & 56.98 & 5.88 & $48.30-65.35$ & 66.19 & 8.08 & $53.04-89.67$ \\
\hline Head width & 64.08 & 7.78 & $55.04-81.01$ & 78.74 & 7.74 & $64.01-98.03$ \\
\hline Interorbital distance & 15.99 & 3.43 & $9.84-21.77$ & 13.44 & 2.56 & $8.64-21.18$ \\
\hline
\end{tabular}


Table 4. Mean $(\bar{x})$ percentage ratios of some morphometric characters of Salmo coruhensis from the Bolaman Stream to standard length and head length, \pm Standard deviation, $m$-M minimum-maximum values

\begin{tabular}{|c|c|c|c|}
\hline & \multicolumn{3}{|c|}{ Salmo coruhensis $(\mathrm{n}=5)$} \\
\hline & $\overline{\bar{x}}$ & \pm & $m$-M \\
\hline Standard Length $(\mathrm{mm})$ & 163.49 & 50.69 & $116.94-230.50$ \\
\hline \multicolumn{4}{|l|}{ In percent of standard length } \\
\hline head length & 25.98 & 2.01 & 24.11-29.88 \\
\hline Maximum body height & 21.96 & 1.20 & $20.59-23.90$ \\
\hline Minimum body height & 9.28 & 0.73 & $8.24-10.28$ \\
\hline Predorsal distance & 45.06 & 1.26 & $43.64-46.76$ \\
\hline Postdorsal distance & 41.73 & 2.08 & $39.63-45.55$ \\
\hline Length of adipose finbase & 4.00 & 0.49 & $3.20-4.58$ \\
\hline Distance between adipose and caudal finbases & 16.94 & 1.07 & $15.35-18.56$ \\
\hline Prepelvic distance & 54.19 & 1.84 & $51.97-56.82$ \\
\hline Preanal distance & 70.91 & 1.01 & $69.55-72.21$ \\
\hline Distance between pectoral and pelvic fins & 30.00 & 0.86 & $29.05-31.32$ \\
\hline Dist. between pelvic and anal fins & 19.62 & 0.61 & $18.91-20.34$ \\
\hline Length of caudal peduncle & 19.09 & 1.54 & $16.79-21.15$ \\
\hline Length of dorsal fin & 13.89 & 0.89 & $12.77-15.07$ \\
\hline Dorsal fin heigth & 18.47 & 1.62 & $15.86-20.16$ \\
\hline Length of anal finbase & 10.84 & 1.14 & $9.76-12.81$ \\
\hline Depth of anal fin & 15.44 & 1.41 & $13.21-16.73$ \\
\hline Length of pectoral fin & 18.13 & 1.07 & $17.28-20.23$ \\
\hline Length of pelvic fin & 14.22 & 0.69 & $13.11-15.16$ \\
\hline \multicolumn{4}{|l|}{ In percent of head length } \\
\hline Head depth (at nape) & 61.82 & 5.17 & $54.11-69.50$ \\
\hline Head depth (at center of eye) & 47.87 & 3.53 & $42.68-52.10$ \\
\hline Preorbital distance & 27.65 & 1.17 & $25.97-29.02$ \\
\hline Horizontal diameter of eye & 20.41 & 1.25 & $18.97-22.70$ \\
\hline Interorbital distance & 29.24 & 1.46 & $27.52-31.43$ \\
\hline Postorbital distance & 50.57 & 2.85 & $47.34-54.91$ \\
\hline Depth of upper jaw & 12.39 & 0.71 & $11.11-13.27$ \\
\hline Upper jaw length & 48.63 & 2.14 & $46.07-51.13$ \\
\hline Lower jaw length & 68.38 & 10.00 & 59.09-83.96 \\
\hline
\end{tabular}




\section{Compliance with Ethical Standard}

Conflict of interests: The authors declare that for this article they have no actual, potential or perceived conflict of interests.

Ethics committee approval: This study was approved with Document Number and Date of 82678388 / 27.01.2016 given by Ordu University Animal Experiments Local Ethics Committee Approval Document.

Funding disclosure: This study was supported by Research Project AR-1697 by Ordu University Scientific Projects Support Coordination Department.

Acknowledgments: I would like to thanks a lot our staff Halil SULUK and Abdülkerim GÖNEZ for their valuable time and efforts in field surveys. I would also like to thank Enes Fatih PEHLIVAN and Filiz SAYGUN for their contributions in the laboratory studies.

Disclosure: Some information's in this article were presented orally at an international symposium and is included in the abstract booklet in International Marine \& Freshwater Sciences Symposium, 18-21 October 2018, Kemer-Antalya / Turkey.

\section{References}

Abbott, K.E. (1835). Letter accompanying a collection from Trebizond and Erzeroun. Proceedings of the Zoological Society of London, Part III, 89-93.

Anonymous (2018). Bolaman Irmağ $;$; 2018. Retrieved from https://de.wikipedia.org/wiki/Bo-

laman Irma\%C4\%9F\%C4\%B1 (accessed 24.05.2019)

Bănărescu, P.M. (1999). The Freshwater Fishes of Europe Volume 5/1 (Cyprinoidae 2): Part 1: Rhodeus to Capoeta. Wiebelsheim: Aula Verlag GmbH, 469 pp, ISBN 3891044315

Bănărescu, P.M., Bogutskaya, N.G. (2002). Barbus Cuvier, 1816. In P.M. Bănărescu, N.G. Bogutskaya (Ed.), The Freshwater Fishes of Europe Volume 5/II: (Cyprinoidae 2/II): Barbus (pp. 1-10). Wiebelsheim: Aula Verlag GmbH, 454pp, ISBN 3891046593

Bănărescu, P.M., Paepke, H.J. (2003). The Freshwater Fishes of Europe Volume 5/III: Cyprinoidae 2: Part III: Carassius to Cyprinus, Gasterosteidae. Wiebelsheim: Aula Verlag GmbH, 305pp, ISBN 38910446586

Bektaş, Y., Beldüz, A.O., Turan, D. (2013). The phylogenetic position of Turkish populations within the European
Bitterling, Rhodeus amarus (Osteichthyes: Cyprinoidae). Zoology in the Middle East, 59(1), 39-50.

https://doi.org/10.1080/09397140.2013.795063

Bektas, Y., Aksu, I., Kaya, C., Bayçelebi, E., Küçük, F., Turan, D. (2020). Molecular systematics and phylogeography of the genus Alburnus Rafinesque, 1820 (Teleostei, Leuciscidae) in Turkey. Mitochondrial DNA Part A, 31(7), 273284.

https://doi.org/10.1080/24701394.2020.1791840

Bostancı, D., İskender, R., Helli, S., Polat, P. (2015). Turnasuyu Deresi (Ordu) balık faunasinın belirlenmesi. Ordu Üniversitesi Bilim ve Teknoloji Dergisi, 5(2), 1-9.

Bostancı, D., İskender, R., Helli, S., Polat, N. (2016). The fish of the Curi stream (Ordu) and invasive fish species Carassius gibelio (Bloch, 1782). Journal of Aquaculture Engineering and Fisheries Research, 2(1), 11-19.

https://doi.org/10.3153/JAEFR16002

Çiçek, E. (2020). Seminemacheilus dursunavsari, a new nemachelid species (Teleostei: Nemacheilidae) from Turkey. Iranian Journal of Ichthyology, 7(1), 68-77.

Çiçek, E., Sungur, S., Fricke, R. (2020). Freshwater lampreys and fishes of Turkey; a revised and updated annotated checklist 2020. Zootaxa, 4809(2), 241-270.

https://doi.org/10.11646/zootaxa.4809.2.2

Darçın, M. (2014). The determination of fish fauna of Ilıca and Yalıköy Streams (Ordu). Ordu University, Institute of Natural Sciences, Master Thesis, Ordu, 99pp.

Dönel, K.E., Yılmaz, E. (2016). Gaga Gölü (Ordu-Türkiye) balık faunası ve tespit edilen 4 türün morfometrik karakterleri. Türk Denizcilik ve Deniz Bilimleri Dergisi, 2(2), 63-74.

Freyhof, J. (2014). Alburnus derjugini. The IUCN Red List of Threatened Species 2014, e.T19018463A19222773. 2014. https://doi.org/10.2305/IUCN.UK.20141.RLTS.T19018463A19222773.en

Fricke, R., Eschmeyer, W.N., Fong, J.D. (2020). Species by family/subfamily. Catalog of fishes; 02 November 2020. Retrieved from http://researcharchive.calacademy.org/research/ichthyology/catalog/SpeciesByFamily.asp (accessed 18.11.2020).

Froese, R., Pauly, D. (2019). List of Freshwater Fishes reported from Turkey (update ver. 12/2019). Retrieved from 
https://www.fishbase.se/Country/CountryChecklist.php?c code $=792 \&$ vhabitat $=$ fresh \&csub $\operatorname{code}=$ (accessed 16.06.2020)

Holčík, J. (1989). The Freshwater Fishes of Europe Volume 1/II General Introduction to Fishes Acpenseriformes. Wiebelsheim: Aula Verlag GmbH, 469pp, ISBN: 38991044315

Kalaycı, G., Öztürk, R.C., Çapkın, E., Altınok, I. (2018). Genetic and molecular evidence that brown trout Salmo trutta belonging to the Danubian lineage are a single biological species. Journal Fish Biology, 93(5), 792-804.

https://doi.org/10.1111/jfb.13777

Kaya, C., Turan, D., Bayçelebi, E., Kalaycı, G., Freyhof, J. (2020a). Oxynoemacheilus cilicicus, a new nemacheilid loach from the Göksu River in southern Anatolia (Teleostei: Nemacheilidae). Zootaxa, 4808(2), 284-300.

https://doi.org/10.11646/zootaxa.4808.2.3

Kaya, C., Turan, D., Kalaycı, G., Bayçelebi, E., Freyhof, J. (2020b). Discovery of the westernmost known population of Paracobitis (Teleostei, Nemacheilidae) with the description of a new species from the Euphrates River in southern Anatolia. Zootaxa, 4838(4), 525-534.

https://doi.org/10.11646/zootaxa.4838.4.6

Kaya, C. (2020). New record of three freshwater fish species from a western drainage of Lake Urmia for the Turkish fauna. Ege Journal of Fisheries and Aquatic Sciences, 37(4) (in press).

Kottelat, M., Freyhof, J. (2007). Handbook of European Freshwater Fishes. Cornol: Publications Kottelat, 646pp, ISBN: 2839902984

Kuru, M. (2004). Türkiye İçsu Balıklarının Son Sistematik Durumu. Gazi Üniversitesi Gazi Eğitim Fakültesi Dergisi, 24(3), 1-21.

Miller, P.J. (2003). The Freshwater Fishes of Europe Volume 8, Part I: Mugilidae, Atherinidae, Atherinopsidae, Blenniidae, Odonotbutdae, Gobiidae 1. Wiebelsheim: Aula Verlag GmbH, 404pp, ISBN: 3891046685

Özuluğ, M., Freyhof, J. (2011). Revision of the genus Squalius in Western and Central Anatolia, with description of four new species (Teleostei: Cyprinidae). Ichthyological Exploration of Freshwaters, 22(2), 107-148.
Saygun, S., Turan, D., Saygun, F., Kabadayı, M., Yılmaz, H.F., Ataç Şahin, T. (2017). Contributions to fish fauna of the Ilica River (Fatsa/Turkey). Biological Diversity and Conservation, 10(2), 141-154.

Stoumboudi, M., Kottelat, M., Barbieri, R. (2006). The fishes of the inland waters of Lesbos Island, Greece. Ichthyological Exploration of Freshwaters, 17(2), 129-146.

Tan, M., Armbruster J.W. (2018). Phylogenetic classification of extant genera of fishes of the order Cypriniformes (Teleostei: Ostariophysi). Zootaxa, 4476(1), 006-039. http://dx.doi.org/10.11646/zootaxa.4476.1.4

Turan, D., Kottelat, M., Ekmeçi, F.G., İmamoğlu, H.O. (2006). A review of Capoeta tinca, with descriptions of two new species from Turkey (Teleostei: Cyprinoidae). Revue Suisse De Zoologie, 113, 421-436.

https://doi.org/10.5962/bhl.part.80358

Turan, D., Taş, B., Çilek, M., Yılmaz, Z. (2008). Fish fauna of the lower part of River Melet (Ordu, Turkey). JournalFisheriesSciences.com, 2(5), 698-703

https://doi.org/10.3153/jfscom.2008037

Turan, D., Kottelat, M., Engin, S. (2009). Two new species of trouts, resident and migratory, sympatric in streams of northern Anatolia (Salmoniformes: Salmonidae). Ichthyological Exploration of Freshwaters, 20(4), 333-364.

Turan, D., Doğan, E., Kaya, C., Kanyılmaz, M. (2014). Salmo kottelati, a new species of trout from Alakır Stream, draining to the Mediterranean in southern Anatolia, Turkey (Teleostei, Salmonidae). ZooKeys, 462, 135-151.

https://doi.org/10.3897/zookeys.462.8177

Turan, D., Kaya, C., Bayçelebi, E., Bektaş, Y., Ekmekçi, F.G. (2017). Three new species of Alburnoides from the southern Black Sea basin (Teleostei: Cyprinidae). Zootaxa, 4242(3), 565-577.

https://doi.org/10.11646/zootaxa.4242.3.8

Verep, B., Turan, D., Kováč, V. (2006). Preliminary results on morphometry of Barbel (Barbus tauricus Kessler, 1877) in the Streams of Rize and Artvin provinces (Turkey). Turkish Journal of Fisheries and Aquatic Sciences, 6, 17-21.

Yılmaz, E. (2016). Elekçi Irmağı (Fatsa/Ordu) balık faunası. Süleyman Demirel University Journal of Sciences, 11(2), 112. 